\title{
Something or Somebody? The Human Embryo Between Protection of Life and Interest in Scientific Research
}

\author{
Diego Zannoni* \\ University of Padua, Padua, Italy \\ diego.zannoni@unipd.it
}

$\begin{array}{lr}\text { Abstract } & 381 \\ \quad \text { Keywords } & 382 \\ \text { I. Introduction } & 382 \\ \text { II. The Embryo Dilemma } & 384 \\ \text { III. The Self-Restraint of the Court } & 387 \\ \text { IV. The Focus on the Right to Private Life of Potential Donors } & 391 \\ \text { V. The Member States' Margin of Appreciation } & 395 \\ \text { VI. The Limits of the Margin of Appreciation } & 408 \\ \text { VII. The Creation of Embryos, Parthenotes and Clones for Scientific Purposes } & 404 \\ \text { VIII. Proportionality Assessment } & 407 \\ \text { IX. Final Remarks }\end{array}$

\begin{abstract}
Research on human embryos has great potentialities in terms of developing new therapies and increasing scientific knowledge. It is nonetheless ethically and legally controversial. This paper seeks to establish whether the European Convention on Human Rights and the Convention on Human Rights and Biomedicine provide a key to accommodate the tension between protection of the human embryo and interest in scientific research. Without a proper analysis of the issue, the risk is that of accepting the evolution of scientific and medical practice as a fait accompli, as if whatever is possible for science were legitimate in law, or will be eventually. This paper consistently identifies the legal limits within which scientific research must be carried out and then assesses the reasonableness of a blanket ban on carrying out scientific research on embryos. Only the passing of time will show us whether the legal limits which arguably cannot be exceeded today will be able to stand up against the impact of scientific progress.
\end{abstract}

\footnotetext{
* Researcher in International and European Union Law, University of Padua, Department of Political Science, Law, and International Studies, Via del Santo, 28 - 35123 Padua, Italy.
} 


\section{Keywords}

Embryo - stem cells - right to life - human being - scientific research

\section{Introduction}

Stem cells obtained from embryos are defined as pluripotent as they possess the potential to become any tissue that makes up the human body. Because of this capacity, they might constitute a renewable source of replacement cells and tissues for the treatment of several diseases that, up to now, have been incurable or not effectively curable, including Parkinson's and Alzheimer's diseases, to name but two. Research with stem cells and their therapeutic use are nonetheless ethically controversial. Indeed, at the current stage of technical and scientific knowledge, the creation of stem cells inevitably involves the destruction of the embryo from which they are derived. Therefore, the potential benefits in terms of scientific knowledge and the development of cell-based therapies clash with protection of the human embryo.

The aim of this work is to define the status of the human embryo in general and in particular of so-called 'spare embryos' - embryos obtained through in vitro fertilisation techniques which are not then implanted. ${ }^{1}$ In states where scientific research on embryos is prohibited, spare embryos are indefinitely cryopreserved in liquid nitrogen at $-196^{\circ} \mathrm{C}$ until their natural extinction. A delicate bioethical and legal issue arises here because of their paradoxical fate: they were initially created to live and end up to dying without being born. Given the delicate balance at stake, it is unsurprising that the Additional Protocol on Biomedical Research excludes research on embryos in vitro from its scope of application, ${ }^{2}$ and that the Protocol on the Protection of the Human Embryo and Foetus was only drafted and then never adopted.

To avoid or at least mitigate the spare embryos issue, domestic legislation commonly established a maximum number of embryos to be created for each in vitro fertilisation treatment, coupled with an obligation to simultaneously

1 The ECtHR includes within the right to family life the right to have children, if necessary, through assisted fertilisation techniques, which the state has the positive obligation to grant. ECtHR, Knecht v. Romania, judgment of 2 October 2012, Application no. 10048/10, para. 54.

2 Additional Protocol to the Convention on Human Rights and Biomedicine, concerning Biomedical Research, 25 January 2005, Article 2 para. 2. 
implant them all. However, in the cases of women of an older age, the generally low rate of success of artificial fertilisation often made it necessary to restart with a further cycle of ovarian stimulations and egg extraction after failure of the first attempt, jeopardising the woman's health. For younger women, in contrast, the need to proceed with a single and simultaneous implantation entailed a risk of multiple pregnancies with potentially harmful consequences for themselves and future foetuses. For this reason, the prohibition on creating more embryos than a specific number was gradually removed from domestic legislation. ${ }^{3}$ This removal, in combination with the now accepted possibility of selecting embryos unaffected by genetic diseases through preimplantation diagnosis, brought an exacerbation of the spare embryos issue as a side-effect. ${ }^{4}$

This paper seeks to establish whether the European Convention on $\mathrm{Hu}-$ man Rights (ECHR) and the Convention on Human Rights and Biomedicine (hereafter the Oviedo Convention) $)^{5}$ provide a key to accommodate the tension between protection of the human embryo and interest in scientific research. Of course, the Oviedo Convention does not produce any international obligations for countries such as Italy, which have not ratified it, or for countries like Germany, which are not even signatories to it. Therefore, the Oviedo Convention cannot be said to be a formal legal source for these countries. Nevertheless, the ratification and signing of the Oviedo Convention and its Protocols by a large number of states is a strong indication that a growing European consensus has been built around it, which could therefore be interpreted as a sign of a narrowing of the Council of Europe member states' margin of appreciation. The European Court of Human Rights (ECtHR) has taken the Oviedo Convention as a reference to interpret ECHR

3 See Italian Constitutional Court, judgement of 8 May 2009, decision no. 151/2009. The Italian Constitutional Court explicitly admitted the causal link between the removal of a maximum number of embryos to be created and exacerbation of the spare embryos issue in Italian Constitutional Court, judgment of 22 March2016, decision no. 84/2016, para. 8.2.

4 In Costa and Pavan v. Italy, the ECtHR concluded that the Italian prohibition on access to preimplantation genetic diagnosis was in violation of the ECHR. ECtHR, Costa and Pavan v. Italy, judgment of 28 August 2012, Application no. 54270/10. On this issue, see Ludovica Poli, 'La diagnosi genetica pre-impianto al vaglio della Corte europea dei diritti dell'uomo', Riv. Dir. Int. 96 (2013), 119-134; Giuseppe Cataldi, 'La giurisprudenza della Corte europea dei diritti dell'uomo in materia di diagnosi genetica preimpianto', in: Rosanna Fattibene (ed.) La diagnosi genetica preimpianto tra normativa e giurisprudenza, (2017), 183-198.

5 Convention for the Protection of Human Rights and Dignity of the Human Being with regard to the Application of Biology and Medicine: Convention on Human Rights and Biomedicine, Oviedo, 4. April 1997, European Treaty Series - No. 164 (hereafter Oviedo Convention). 
norms in a number of cases. ${ }^{6}$ It has thus become a material source of law for all the European Union (EU) member states for the twofold reason of their being parties to the ECHR and because the Court of Justice of the EU makes reference to ECtHR jurisprudence to interpret the EU Charter of Fundamental Rights. Some principles affirmed in the 'Oviedo system' are directly binding on the EU member states in any case, albeit only concerning cases regulated by EU law, because they are reiterated in Articles 1 and 3 of the EU Charter of Fundamental Rights. ${ }^{7}$

The issue of the admissibility of invasive, manipulative, and destructive experiments on human embryos and the related issue of the degree of legal protection and dignity recognised to the human embryo fall within this framework. The interests involved and the related ECHR parameters are intuitively multiple. On the one hand, the protection due to the embryo needs to be better clarified. On the other hand, there is the right of potential 'donors' to self-determination in relation to the use of their embryos and the freedom of scientific research. It is admittedly true that, unlike the EU Charter of Fundamental Rights, ${ }^{8}$ the ECHR does not contain a provision protecting scientific research. In the Court's case law, the protection of scientific research is nonetheless traced back to the freedom of expression, and so to Article 10 ECHR. ${ }^{9}$

\section{The Embryo Dilemma}

The answer to the question of the permissibility of research on embryos which are no longer - or have never been - part of a parental project

6 For references to the Oviedo Convention and to its additional Protocols, albeit within the field of application of the ECtHR, see ECtHR, Glass $v$. the United Kingdom, judgment of 9 March 2004, Application no. 61827/00, para. 58; ECtHR, Vo v. France, judgment of 8 July 2004, Application no. 53924/00, paras 35 and 84; ECtHR, Evans v. the United Kingdom, judgment of 10 April 2007, Application no. 6339/05, para. 50. On the ECtHR's use of other international instruments to interpret the ECHR, see Cesare Pitea, 'Interpreting The ECHR In the Light of "Other" International Instruments: Systemic Integration or Fragmentation of Rules on Treaty Interpretation?' in: Nerina Boschiero, Tullio Scovazzi, Cesare Pitea and Chiara Ragni (eds), International Courts and the Development Of International Law (Heidelberg/Berlin: Springer 2013), 545-559.

7 The Explanations Relating to the Charter of Fundamental Rights note that the principles in its Article 3 were already included in the Oviedo Convention and the Charter does not set out to depart from them. See the Explanations Relating to the Charter of Fundamental Rights (doc. no. 2007/C 303/02).

8 See, Article 13 EU Charter of Fundamental Rights.

9 See, ECtHR, Mustafa Erdoğan and Others v. Turkey, judgment of 27 May 2014, Applications nos 346/04 and 39779/04, paras 40-41. 
essentially depends on what meaning is attributed to the word 'person' and correlatively on the moment when human life is assumed to begin.

According to a first thesis, a human person exists from fertilisation, with the consequence that no intervention on the human embryo is admitted after that event unless it is aimed at the protection of the specific embryo. As a corollary, human stem-cell lines to be used for scientific or therapeutic purposes should be obtained from other sources, for instance from adults or the umbilical cords of new-born babies. ${ }^{10}$ In contrast, according to a second thesis, during an initial period of development after fertilisation there is not a human person and not even an embryo. Therefore, scientific research could well be carried out during this 'pre-embryonic' phase. This period is, however, not unequivocally defined. Fertilisation, implantation, the appearance of the four-cell embryo or the primitive streak and the loss of the potential to develop into two or three individual embryos have alternatively been proposed as decisive criteria to define when a human life begins.

A powerful argument to support the first thesis is that from the very moment of fertilisation the human embryo belongs to the human species. Some philosophers and legal scholars derive from this fact that an embryo is entitled to a right to life (species argument). ${ }^{11}$ According to this thesis, the penetration of a spermatozoa into the oocyte cytoplasm is the first, irreversible, and fundamental event from which the process begins of constituting and developing a person. The necessary genetic information is already there. ${ }^{12}$ Even if one admits for a while that it is not possible to precisely establish the

10 In this sense, Giovanna Razzano, 'Corte costituzionale n. 84 del 2016, sulla tutela dell'embrione e l'interesse della ricerca scientifica: una sentenza ispirata alla prudentia?’, Biolaw Journal No. 2 (2016), 223-244 (242). The EU Parliament also 'urges maximum political, legislative, scientific and economic efforts to be aimed at therapies that use stem cells taken from adult subjects'. EU Parliament Resolution Human Cloning, 7 September 2000, para. 5.

11 In this sense, see Robert Spaemann, Persone. Sulla differenza tra 'qualcosa' e 'qualcuno', (Rome/Bari: Laterza 2005) (translation by L. Allodi), 241; Adriano Pessina, Bioetica. L'uomo sperimentale, (Milan: Mondadori 1999), 93.

12 'Unborn human life is not different in essence from born life. Human embryos must be treated in all circumstances with the respect due to human dignity. Scientific research applications concerning the human genome, in particular in the field of genetics, do not prevail over the respect for human dignity. Scientific progress must not be built upon disrespect for ontological human nature. The scientific goal of saving human lives does not justify means that are intrinsically destructive of that life.' ECtHR, Parrillo v. Italy, judgment of 27 August 2015, Application no. 46470/11, Concurring Opinion of Judge Pinto de Albuquerque, para. 43. See also the Advisory Opinion of the Comitato nazionale per la bioetica (Italian National Bioethics Committee), Bioethical considerations concerning the so-called 'ootid', 15 July 2005, 5. According to the Committee, the beginning of human life is the breakthrough, the passage from the not-being to being. From that moment, there are only quantitative, not qualitative modifications (continuity argument). 
moment in which a simple group of cells becomes a person, it is precisely because of the potential to become a person that a human embryo should be respected as if it were already a person (potentiality argument). In other words, since any differentiation after the moment of conception is arbitrary, a precautionary approach would require all stages of human life to be covered with the same level of protection.

One might conversely argue that if ' $a$ ' has the potential to become ' $A$ ' they are not ontologically the same. ${ }^{13}$ In more concrete terms, just because an embryo has the potential to become a person, it does not mean that we should treat it as if it was already a person. To say that an embryo must be recognised as a potential person does not solve the problem because an entity that is recognised as a potential being is not necessarily a being and may in fact, by converse implication, not be one. Moreover, potentiality by definition requires a certain probability for the embryo to develop into a person as a natural course of development without external interference. But it is obvious that an in vitro embryo is not yet able to survive without being implanted in the mother's uterus and develop in the mother's womb. It is therefore dependent on external interference in order to become a person and as such lacks the potential for independent development. Consequently, the potentiality argument, too, does not seem sufficient to justify why the life of an embryo in vitro should be protected.

Against the second thesis, one might emphasise that mere biological facts alone do not allow normative consequences to be drawn. For instance, biology can clarify when fertilisation occurs and when the four-cell embryo or the primitive streak appears. Biology can identify the stage in which the embryo has lost its potential to develop into two or three individual embryos. However, these events could be nothing but conventional borderlines when they are assumed as criteria for establishing the beginning of human life. It is, in fact, at the bio-ethical and not at the scientific level that discussion develops on the 'beginning of human life' or on the possible stages of development with which certain rights might be connected..$^{14}$

The conundrum outlined is apparently not easy to solve because all the arguments supporting one thesis or another are rebuttable. ${ }^{15}$ The disagreement on the admissibility of scientific research on the human embryo ultimately reflects different assessments of the ontological condition of the embryo, and different balances between the values and interests at stake.

13 While stressing that the concept of 'child' cannot be put in the same category as that of 'embryo'. Costa and Pavan v. Italy (n. 4), para. 62.

14 Razzano (n. 10), 239-240.

15 In this sense, see also Niels Petersen, 'The Legal Status of the Human Embryo in vitro: General Human Rights Instruments’, HJIL 65 (2005), 447-466 (453). 
From a 'reductionist' perspective, an embryo is conceived as an agglomeration of cells. In contrast, according to a personalist and sacred concept of human life, the embryo's life is an aim in itself and no individual, including embryos, is to be reduced to an instrument for the use of another.

\section{The Self-Restraint of the Court}

Article 2 ECHR does not define the 'everyone' (toute personne in French) whose life is to be protected or the term 'life'. The travaux préparatoires on the Convention are silent on the scope of these words and on whether Article 2 is applicable prior to birth. The Oviedo Convention does not help to solve the conundrum and to some extent exacerbates it because it uses different terms even within the same provision, namely 'human beings' and 'everyone' - 'toute personne' in French - without providing any definition of them. Therefore, the Oviedo Convention does not clarify whether an embryo, for example, falls into one of the categories or neither. Nor is there any specification concerning the beginning of human life. The Explanatory Report of the Oviedo Convention specifies that in the absence of a unanimous agreement on the definition of these terms among member states of the Council of Europe it was decided to allow domestic law to define them for the purposes of the application of the Convention. ${ }^{16}$ The same is true of the Additional Protocol on the Prohibition of Cloning Human Beings and the Additional Protocol on Biomedical Research, neither of which define the concept of 'human being'. ${ }^{17}$ The EU Charter of Fundamental Rights likewise uses the

16 Explanatory Report to the Oviedo Convention, 4. April 1997, para. 18 (hereafter Explanatory Report). Along the same lines, the preamble to Directive 2004/23/EC specifies that 'this Directive should not interfere with provisions of Member States defining the legal term "person" or "individual". The Directive therefore assumes that the two concepts do not, or at least may not, overlap. Cf. Directive 2004/23/EC of the European Parliament and of the Council of 31 March 2004 on setting standards of quality and safety for the donation, procurement, testing, processing, preservation, storage and distribution of human tissues and cells [2004] OJ L102, recital no. 12. On the related philosophical debate, see Pessina (n. 11), 79-81; Paolo Zatti, Maschere del diritto volti della vita, (Milan: Giuffrè 2009), 15-21.

17 Explanatory Report to the Additional Protocol on the Prohibition of Cloning Human Beings, para. 6; Explanatory Report to the Additional Protocol on Biomedical Research, para. 13; 'In relation to Article 1 of the Protocol on the Prohibition of Cloning Human Beings, the Government of the Kingdom of the Netherlands declares that it interprets the term "human being" as referring exclusively to a human individual, i. e. a human being who has been born.' Declaration contained in a Note Verbale from the Permanent Representation of the Netherlands, dated 29 April 1998, handed to the Secretary General at the time of signature, on 4 May 1998. 
terms 'human being' and 'person' even within the same provision without providing any definition. ${ }^{18}$

Turning back to the ECHR, both the former Commission and the Court have considered many sensitive cases which have posed fundamental questions concerning either potential, early, embryonic, or foetal human life and its interconnection with the rights of others. While the Commission and the Court have found that matters related to procreation - and, in particular, to the decision to become or not become a parent - constitute an aspect of a person's private life, they have only developed an 'assuming that' argument on the fundamental question as to when 'protected life' under the Convention begins, and have in this manner refrained from pronouncing on the subject. ${ }^{19}$

One could rely on the wording and structure of Article 2 ECHR to conclude that this norm does not apply to the unborn or to the embryo. First, the exceptions to the general prohibition that 'no one shall be deprived of his life intentionally' are exhaustively set out in the second sentence and in paragraph 2 and by their nature concern persons already born. They cannot apply to the foetus and even less to the embryo. Moreover, if this article really referred to human life from conception, voluntary abortion, and destruction of embryos for scientific research as causes of legitimate limitation to the right to life should have been referred to somewhere in the text of Article 2, which is not the case. Member states that have laws permitting abortion and scientific research on embryos could not have ratified the ECHR without reservation if they had interpreted the article as protecting the life of the foetus and embryo. Moreover, in virtue of Article 2 ECHR, states would come under an obligation to take measures to criminalise such conduct to discharge their obligation to protect life. Such an interpretation of Article 2 would apparently have far-reaching consequences - in particular with regard to the admissibility of abortion. ${ }^{20}$ In sum, the systematic struc-

18 While the right to life and integrity refers to 'everyone' (Article 2 para. 1 and Article 3 para. 1), the prohibition of reproductive cloning concerns 'human beings' (Article 3 para. 2). For an analysis of the issue with reference to other international instruments, see Angela Di Stasi, "Alla ricerca di una nozione giuridica di "embrione umano": il contributo del judicial dialogue tra Corti internazionali', at <www.federalismi.it>, Focus Human Rights, (1/2015), 120.

19 See European Commission of Human Rights, ex multis Paton v. The United Kingdom, 13 May 1980, Application no. 8416/78, para. 23; European Commission of Human Rights $R$. H. v. Norway, 19 May 1992, Application no. 17004/90, para. 1; Vo v. France (n. 6), para. 85.

20 In this sense, see Goldman, who argues that Article 2 was not written with the intention of protecting the foetus. Tanya Goldman, 'Vo v. France and Fetal Rights: The Decision not to Decide', Harvard Human Rights Journal 18 (2005), 277-282 (281-282); see also Aurora Plomer, 'A Foetal Right to Life?', HRLR (2005), 311-338 (331). 
ture of Article $2 \mathrm{ECHR}$, the exceptions set out in its paragraph 2 and the absence among them of voluntary abortion and scientific research on human embryos would militate in favour of holding that Article 2 does not apply to the unborn child nor to the embryo.

However, one could rebut all these arguments and note that the first sentence in Article 2 imposes a broader obligation on the state than that contained in the second sentence. The statement that 'everyone's life shall be protected by law' enjoins the state not only to refrain from taking a person's life 'intentionally' but also to take appropriate steps to safeguard life, arguably every human life, including that of the embryo. ${ }^{21}$ Then, the fact that various provisions in the ECHR contain guarantees which by their nature cannot extend to the unborn cannot alter that position. If by their very nature the scope of such provisions can only extend to persons who have been born, it does not preclude the conclusion that other provisions such as the first sentence in Article 2 incorporate protection of the lives of human beings, even in the initial stage of their development. Moreover, if applicability of Article 2 ECHR to the foetus were excluded in cases where it was at stake the Court should have rejected the complaint under Article 2 ECHR as manifestly illfounded. On the contrary, the Court not only dealt with the merits but also addressed the adequacy of non-criminal remedies against a breach of Article 2 ECHR. At the end of the day, by using the 'even assuming' formula in connection with the applicability of Article 2, and by linking the life of the foetus to the life of the mother ('the life of the foetus was intimately connected with that of the mother and could be protected through her'22) the Court surreptitiously brought Article 2 ECHR to the fore.

Against the argument that abortion does not constitute one of the exceptions expressly listed in Article 2 paragraph 2, and would therefore consequently have to be forbidden if Article 2 applied to the foetus and to the embryo, one might conversely object that, after all, even in abortion cases, by applying the 'fair balance' test between the interests of the mother and those of the foetus, the Court implicitly considered the protection of Article 2 applicable to the latter. In fact, what other right could a foetus be entitled to if not the right to life? That Article 2 ECHR first paragraph also covers prenatal life does not necessarily mean that the lives of the mother and foetus are considered to be on equal legal ground. If one admits the applicability of Article 2 in the initial stage of pregnancy, one should also admit that this

21 On the positive obligations stemming from Article 2 ECHR to safeguard life, see ECtHR, Osman v. the United Kingdom, judgment of 28 October 1998, Application no. 87/ 1997/871/1083, para. 115; Vo v. France (n. 6), para. 88.

22 Vo v. France (n. 6), para. 86. 
provision contains an implied limitation on the foetus's right to life, to protect the life and health of the mother in that stage. ${ }^{23}$ In other words, abortion is compatible with Article 2 in the interests of protecting the mother's life and health. In similar terms, the protection of the human life of the embryo should be admitted but it does not mean that this protection should be understood in absolute terms.

Finally, that there must be protection of life before birth seems to be a principle that is shared by all the member states of the Council of Europe, as domestic legislation permitting the voluntary termination of pregnancy submits it to stringent requirements and would not be necessary if the foetus was not regarded as having a life that should be protected. Abortion therefore constitutes an exception to the rule that the right to life should be protected even before birth. States admitting research on human embryos likewise carefully regulate the activity and set out temporal limits from fertilisation for scientific research to be lawfully carried out. Even the Draft Protocol on the Protection of the Human Embryo and Foetus coherently established a temporal limit for scientific research: 'It is prohibited to maintain an embryo in culture for research purposes beyond 14 days or until the appearance of the primitive streak.' 24

Against the background of these opposite arguments, it is unsurprising that the Court has refrained from pronouncing on the question as to when 'protected life' begins under the Convention. The Court has often emphasised that solving this conundrum was not necessary for a final ruling ${ }^{25}$ and

23 European Commission of Human Rights, X. v. the United Kingdom, 13 May 1980, Application no. 8416/79, 252-253; Vo v. France (n. 6), para. 80; on the need to weigh the woman's rights and interests against the competing rights and interests of the unborn child, see ECtHR, $A, B$ and $C$ v. Ireland, judgment of 16 December 2010, Application no. 25579/05, para. 213.

24 Article 6 of the Draft Protocol on the Protection of the Human Embryo and Foetus. For a comment, see the Statement by the Italian National Bioethics Committee Concerning the Preliminary Draft Protocol of the Bioethics Committee of the Council of Europe, 31 March 2000.

25 The Commission was more cautious in R. H. v. Norway: 'the Commission finds that it does not have to decide whether the foetus may enjoy a certain protection under Article 2 (Art. 2), first sentence as interpreted above, but it will not exclude that in certain circumstances this may be the case notwithstanding that there is in the Contracting States a considerable divergence of views on whether or to what extent Article 2 (Art. 2) protects the unborn life.' $R$. H. v. Norway (n. 19), para. 1; Paton v. The United Kingdom (n. 19), para. 23; ECtHR, Open Door and Dublin Well Woman v. Ireland, judgment of 29 October 1992, Application no. 14234/88; 14235/88, para. 66; 'La Cour estime n'avoir pas à décider du point de savoir si le foetus peut bénéficier d'une protection au regard de la première phrase de l'article 2 telle qu'interprétée ci-dessus.' ECtHR, Boso v. Italy, judgment of 5 September 2002, Application no. 50490/99, para. 1 in law; it is neither desirable, nor even possible as matters stand, to answer in the abstract the question whether the unborn child is a person for the purposes of Article 2 of the Convention'. Vo v. France (n. 6), para. 85. 
that in any case, given the lack of a European consensus on the scientific and legal definition of the beginning of life, member states enjoy a wide margin of appreciation in this area. ${ }^{26}$ However, the Court has not always been faithful to its declared intent to leave open the question of the possible application of Article 2 ECHR to the unborn foetus and to the embryo. In the Vo v. France case, the Court stated that 'the potentiality of that being and its capacity to become a person [...] require protection in the name of human dignity, without making it a "person" with the "right to life" for the purposes of Article $2^{\prime 27}$ and then, even more clearly, 'the unborn child is not regarded as a "person' directly protected by Article 2 of the Convention". ${ }^{28}$ In the Evans v. The United Kingdom case, the Court likewise concluded that 'the embryos created by the applicant and J. do not have a right to life within the meaning of Article 2 of the Convention'. ${ }^{29}$ It is admittedly true that the Court then retreated from a clear statement of the principle underlying these obiter dicta. But it is no coincidence that the Court in the Parrillo v. Italy case used the expression 'protection of the embryo's potential for life' and not 'right to life'. ${ }^{30}$ The Court's assumption comes out clearly when it considers the donors' choice to 'decide the fate of' and 'make use of' their embryos to be covered under the protective umbrella of Article 8 ECHR: the right to private life of potential donors. This conclusively confirms that, according to the Court, and despite its explicit refusal to take a stand on the matter, an embryo is not a person.

\section{The Focus on the Right to Private Life of Potential Donors}

On the spare embryos issue, two paths of reasoning were available to the ECtHR. A first possibility was to emphasise the protection due to the

26 Vo v. France (n. 6.), para. 82; Evans v. The United Kingdom (n. 6), para. 54; Open Door and Dublin Well Woman v. Ireland (n. 25), para. 68; In doing so, according to Goldman, the Court side-stepped its judicial role to interpret the language of the ECtHR. Goldman (n. 20), 277, 279.

27 Vo v. France (n. 6), para. 84.

28 Vo v. France (n. 6), para. 80.

29 Evans v. The United Kingdom (n. 6), para. 56.

30 Parrillo v. Italy (n. 12), para. 167. In the Parrillo case, the Grand Chamber did not cite the paragraph from Evans quoted in the text. According to Judge Pinto de Albuquerque, this omission is noteworthy and reflects 'the Grand Chamber's uneasiness with the Evans anti-life principle'. Parrillo v. Italy, Concurring Opinion of Judge Pinto de Albuquerque (n. 12), para. 31. 
embryo in virtue of the positive obligations stemming from Article 2 ECHR. ${ }^{31}$ The second path was to adopt a different perspective: not to focus on the potential life of the embryo but on the donors' choice to donate embryos to scientific research or not. The latter is the precise path the Court followed in the Parrillo v. Italy case. In the light of 'the link existing between the person who has undergone in vitro fertilisation and the embryos thus conceived,'32 the Court considered that the person's ability to exercise a choice regarding the fate of their embryos, including donation to scientific research, fell within the right to private life under Article 8 ECHR. ${ }^{33}$ This 'link' was precisely due to the fact that the embryos contain the genetic material of the donor person and accordingly represent a constituent part of that person's genetic material and biological identity. In sum, in the Court's view, when dealing with the fate of spare embryos, there are no possible rights of a foetus at stake but exclusively the right of the donor to act as a free and autonomous individual with regard to their genetic footprint. $^{34}$

As long as the Court leaves matters like 'deciding the fate of' and 'making use of' human embryos to the individual's self-determination, it necessarily

31 'Since the right to life is at stake, it completely changes the judicial approach in accordance with the Court's role in interpreting the Convention, including the positive obligation of the State to safeguard the beginning of life. [...] In my view, the embryo's right to life is a key criterion for reaching the right decision. I am sure that if this criterion had been applied, many previous cases [...] would have been decided in favour of the applicants, who indeed wanted to become parents and, as a result, save the embryo's life'; 'since the right to life is absolute, and is one of the fundamental rights, neither the margin of appreciation nor sovereignty nor consensus is a relevant factor. A margin of appreciation is required only to determine which measures are necessary to protect a fundamental value (for example, public expenditure or a time-limit on the cryopreservation of embryos). The embryo's life cannot be sacrificed for the purpose of inter-State competition in biomedicine.' Concurring Opinion of Judge Dedov in Parrillo v. Italy (n. 12), paras 3-5, 8 .

32 Parrillo v. Italy (n. 12), para. 158. See also Evans v. The United Kingdom, in which the Court defined the donated gametes as the donor's 'genetic material' and on this basis elaborated the rule that no use could be made of them without the donor's continuing consent. Evans $v$. The United Kingdom (n. 6), para. 89. On the consent requirement, see para. 6.

33 Parrillo v. Italy (n. 12), paras 152, 159. The application of the right to respect for family life is of course excluded here, given the absence of any parenthood project.

34 The dissenting opinions are on the contrary very clear in emphasising that: 'The mere sharing of genetic material is an unsafe and arbitrary basis for determining that the fate of one human entity falls within the scope of another person's right to self-determination.' Joint Partly Dissenting Opinion of Judges Casadevall and others, para. 7. Indeed, embryos, like all other human entities inevitably share the genetic DNA of their biological 'parents' but this does not necessarily imply that they can be reduced to constituent parts of anyone else's identity biological or otherwise. See also the Concurring Opinion of Judge Pinto de Albuquerque (n. 12), para. 33 . 
assumes that embryos are not persons. ${ }^{35}$ Indeed, as the term self-determination clearly highlights, and the application of this right in the Court's case law confirms, self-determination is a right of individuals to choose for themselves, not for others. ${ }^{36}$ If embryos were assumed to be persons, the case would not sit comfortably with the formal scheme of law that has been applied to it. Therefore, in adopting this approach, and notwithstanding its feigned neutral position on the issue, the Court endorsed a reductionist view on the ontological condition of the human embryo. This was arguably done at the cost of adopting a line of reasoning coming close to contradiction by acknowledging that the application of Article 2 to embryos is left unsettled while necessarily assuming that an embryo is not a person.

The Court then recognised that the prohibition on scientific research on the human embryo can be traced back to the purpose of protecting the morals, rights and freedoms of others. The Court once again claimed to assume a neutral position because it argued that the word 'others' might be interpreted 'in the terms in which the concept is meant by the [Italian] Government', ${ }^{37}$ that is, encompassing the 'embryo's potential for life', ${ }^{38}$ but then quickly specified that it did not intend to take a stand as to whether the word 'others' extended to human embryos. ${ }^{39}$ On the contrary, as was ascertained above, this is implicitly excluded. Therefore, the 'others' whose rights and freedoms have the capacity to counterbalance the compression of the donor's right to self-determination cannot but be other human beings, who might perceive scientific research on the human embryo as an offence to the

35 In the light of these remarks, one can properly appreciate the Opinions attached to the Judgement: 'With the Court's case law to date, it would have been preferable to find that since prospective parenthood is not an issue in this case, the applicant's right to "self-determination" as an aspect of [their] private life simply does not arise.' Joint Partly Dissenting Opinion of Judges Casadevall and others (n. 34), para. 9. 'The majority assume that because the right to become a parent is an aspect of a person's private life, as is the right to have IVF treatment, both of these rights are unfettered in so far as they are rights to "self-determination", thus forgetting that the exercise of "self-determination" of the progenitors in the latter case may impinge upon the existence of another human life: that of the non-implanted embryo.' Concurring Opinion of Judge Pinto de Albuquerque (n. 12), para. 32. In sum, according to this view, while sharing the genetic make-up of its biological 'parents,' an embryo is at the same time a separate and distinct entity, albeit in the very earliest stages of human development.

36 See ECtHR, ex multis Pretty v. The United Kingdom, judgment of 29 April 2002, Application no. 2346/02, para. 61.

37 Parrillo v. Italy (n. 12), para. 167.

38 Parrillo v. Italy (n. 12), para. 123.

39 Open Door and Dublin Well Woman v. Ireland (n. 25), para. 63 (but in this case the issue of the meaning of the term 'others' was relevant under Article 10 para. 2 ECHR); $A, B$ and $C$ v. Ireland (n. 23), para. 228; Parrillo v. Italy (n. 12), para. 167. 
dignity of the whole of humankind. ${ }^{40}$ In sum, the embryo is not a centre of legal imputation because it is not a person, but it might deserve to be indirectly protected as an object of interest of other persons.

In conclusion, in the Court's reasoning, a human embryo has a dignity worthy of being respected, but not a right to life. This thesis can find legal support in the Oviedo Convention. In distinguishing between human beings and persons, the Oviedo Convention says that state parties shall protect the dignity and identity of all 'human beings' and guarantee 'everyone' - 'à toute personne' in French - respect for their integrity together with other rights and fundamental freedoms. ${ }^{41}$ The different terms used - 'human beings' versus 'everyone'/'à toute personne' - might seem to suggest that only persons are entitled to rights and freedoms. Human beings, arguably including embryos, solely possess dignity. ${ }^{42} \mathrm{~A}$ systematic reading of the Oviedo Convention confirms that, for the purposes of this international instrument, the human embryo is not considered a person. Indeed, Chapter V of the Oviedo Convention - Scientific Research - contains three separate provisions which apply to persons undergoing research, persons not able to consent to research and embryos in vitro, respectively Articles 16, 17, and 18. If embryos were deemed to be persons, the third provision would of course be superfluous since embryos would fall within the scope of the second one: persons not able to consent to research.

However, even the qualification of the embryo as a human being is to be excluded. If an embryo were deemed to be a human being, the whole debate would end before even starting. Article 2 of the Oviedo Convention affirms the primacy of the interest and welfare of the human being over the sole interest of society or science. Since scientific research on an embryo mostly implies an irremediable impairment of its biological structure and potential

40 The argumentative framework developed by the ECtHR seems to echo the teachings of Habermas, according to whom the instrumentalisation of embryos would be reprehensible as damaging the whole of humankind, rather than a 'potential' subject of law. Jürgen Habermas, $I l$ futuro della natura umana. I rischi di una genetica liberale, (Turin: Einaudi 2002) (translation by L. Ceppa), 72. See also PACE Resolution 1352 (2003) on human stem cell research: '[t]he destruction of human beings for research purposes is against the right to life of all bumans and against the moral ban on any instrumentalisation of humans.' Emphasis added. PACE Resolution 1352 (2003), para. 10.

41 Article 1 of the Oviedo Convention.

42 In this sense, see Antonello Tancredi, 'Genetica umana ed altre biotecnologie nel diritto comunitario ed europeo' in: Nerina Boschiero (ed.), Ordine internazionale e valori etici (Editoriale Scientifica: Naples 2004), 381-411 (393-394); Mathieu supports the view that the distinction between person and human being in Article 1 of the Oviedo Convention is not a coincidence. Cf. Bertrand Mathieu, 'De la difficulté d'appréhender l'emploi des embryons humains en termes de droits fondamentaux', RTDH 54/2003, 387-401 (390). 
for further development, the primacy of the human being (read embryo) would logically exclude any scientific research on it. This conclusion is, however, untenable because the Oviedo Convention does not take a stand on the admissibility of 'research on embryos in vitro'. Article 18 of the Oviedo Convention transfers the assessment of whether or not to admit such use to the discretion of the member states.

On the other hand, that an embryo is not a person and not even a human being does not reduce it to a pure possession. It is admittedly true that if spare embryos are not meant to be implanted and thus develop into foetuses and be born they are indefinitely cryopreserved until their natural extinction. One could arguably deduce from this that they do not even have a potential life worthy of being protected. Starting from this premise, the applicant in the Parrillo v. Italy case precisely derived the conclusion that spare embryos should be classified as 'possessions' under the terms in Article 1 of Protocol no. 1 and that a prohibition on using spare embryos for scientific research purposes would not be a justified restriction on the property right the couple enjoys regarding them. ${ }^{43}$

Nevertheless, focusing on the economic and pecuniary scope of Article 1 of Protocol no. 1, the Court categorically excluded human embryos being able to be reduced to 'possessions'. ${ }^{44}$ The rationale for this exclusion seems to simply lie in their being 'human'. Even admitting that an embryo is not yet a 'human being', its abstract potentiality and capacity to become a person is enough to exclude its qualification as a possession. ${ }^{45}$ The Oviedo Convention is clear in stating that where scientific research on human embryos is admitted the embryo shall in any case be protected. ${ }^{46}$ This demonstrates that the human embryo cannot merely be considered a lump of cells. ${ }^{47}$

\section{The Member States' Margin of Appreciation}

The Court sent back the delicate task of striking a balance between opposite values, namely the protection of the potential life of the embryo

43 Parrillo v. Italy (n. 12), paras 203-204.

44 Emphasis added. Parrillo v. Italy (n. 12), para. 215.

45 'At best, it may be regarded as common ground between States that the embryo/foetus belongs to the human race.' Emphasis added. Vo v. France (n. 6), para. 84.

46 Article 18 para. 2 of the Oviedo Convention. On this point see para. 6.

47 On the Oviedo Convention being the point of convergence of European bioethics, see para. 1. 
and the interest in scientific research, to the member states. ${ }^{48}$ To prove that the member states' margin of appreciation is wide, the Court emphasised that the right to donate embryos to scientific research is not a particularly important aspect of a person's existence and identity, ${ }^{49}$ the delicate moral and ethical issues raised by the question ${ }^{50}$ and the lack of a European consensus both on the specific subject ${ }^{51}$ and more in general on the status of the embryo. ${ }^{52}$

This solution is not surprising. The Oviedo Convention itself does not take a stand on the admissibility of scientific research on in vitro embryos and merely requires that where national law allows research on embryos in vitro adequate protection shall be assured to the embryo. ${ }^{53}$ Directive 2004/ 23/EC follows the same approach. On the one hand, it leaves to the member states the decision on the use or non-use of any specific type of human cells, including germ cells and embryonic stem cells. ${ }^{54}$ On the other hand, it specifies that if any particular use of such cells is authorised in a member state

48 Its reliance on the margin of appreciation has often been criticised for being a Pilatesque attitude by the Court. Elisa Chieregato, 'La resistenza del divieto di donazione di embrioni alla ricerca scientifica tra margine di apprezzamento europeo e deferenza al legislatore', Forum di Quaderni Costituzionali 5/2016, 1-16 (12). See also Anne-Blandine Caire, 'Persistance des incertitudes sur le statut de l'embryon', RTDH 107 (2016), 733-747 (745). 'Reference to the lack of European consensus as a decisive indicator of the absence of a certain meaning or scope of a Convention right disregards the Preamble to the Convention, which refers to the 'further realisation of human rights' as one of the methods for pursuing the aim of the Convention.' Cf. Dissenting Opinion of Judge Sajó, in Parrillo v. Italy (n. 12), in footnote n. 4. One should nonetheless admit that when the Court enters into the merit of an ethically sensitive issue, it might be thus criticised, this time because in so doing it imposes one exclusive moral code and ends up replacing the member states' authority, losing sight of the subsidiary nature of the Convention mechanism. For the view according to which the Court's self-restraint in the area of research on embryos is shareable, see Antonio Iannuzzi, 'La giurisprudenza della Corte Europea dei diritti dell'uomo sui limiti alla ricerca scientifica' in: Antonio Iannuzzi (ed.) La ricerca scientifica fra possibilità e limiti, (Naples: Editoriale Scientifica 2015), 61-81 (80-81). The striking of a balance between the duty to assure the protection of the rights granted by the ECHR and the respect due to member state's particularities, is admittedly not an easy task for the Court. On this issue, see Ronald J. Macdonald, 'The margin of appreciation' in: Ronald J. Macdonald, Franz Matscher and Herbert Petzold, The European System for the Protection of Human Rights (Dordrecht/Boston/London: Martinus Nijhoff Publishers 1993), 83-124.

49 Parrillo v. Italy (n. 12), para. 174.

50 Parrillo v. Italy (n. 12), para. 176.

51 Parrillo v. Italy (n. 12), para. 176.

52 Vo v. France (n. 6), para. 84.

53 Article 18 para. 1 of the Oviedo Convention. The Explanatory Report limits itself to rephrasing the rule without adding anything.

54 Directive 2004/23/EC on setting standards of quality and safety for the donation, procurement, testing, processing, preservation, storage, and distribution of human tissues and cells (n. 16), recital n. 12. 
the application of all provisions necessary to protect public health and guarantee respect for fundamental rights is required. ${ }^{55}$

The Council of Europe member states coherently show the most different legal solutions to this issue. Some states allow scientific research on spare embryos. Other states allow research on human embryonic cell lines - which originate from the destruction of embryos in the first days of their development - as long as they are imported from abroad, but not on embryos. ${ }^{56}$ Certain other states have enacted legislation expressly prohibiting any research either on embryonic cells or embryos. Some states prohibit research on embryos derived from fertilisation but permit research on those 'embryos' derived from the transfer of the cell nucleus of a mature human cell into a non-fertilised and enucleated human ovum (this is so-called therapeutic cloning). ${ }^{57}$

It remains that if in a given area states enjoy a wide margin of appreciation, the Court is nonetheless called upon to assess whether national measures falling within that area are reasonable and proportionate to reach a legitimate aim which the ECHR considers worthy of protection. ${ }^{58}$ The national margin of appreciation is therefore not unlimited. ${ }^{59}$

55 Directive 2004/23/EC on setting standards of quality and safety for the donation, procurement, testing, processing, preservation, storage, and distribution of human tissues and cells (n. 16).

56 This is the case of Italy. Italian law no. 40/2004 prohibits research on human embryos if not carried out for therapeutic or diagnosis purposes for the benefit of the specific embryo under analysis (see Law no. 40/2004, Article 13, paras 1 and 3 b). At the same time, scientific research is allowed on cell lines imported from abroad. On this issue the Court agreed with the Italian Government and argues that 'the deliberate and active destruction of a human embryo cannot be compared with the use of cell lines obtained from human embryos destroyed at an earlier stage'. Parrillo v. Italy (n. 12), para. 194. It seems, on the contrary, that if the blanket ban on scientific research on human embryos lies in their human dignity and potential for life - this was the position of the Italian Government - it is hard to justify why 'foreign embryos' can be destroyed unless one admits that they have less dignity than Italian embryos! In this sense, see also Carlo Casonato, 'Sensibilità etica e orientamento costituzionale. Note critiche alla sentenza della Corte costituzionale n. 84 del 2016', Biolaw Journal 2/2016, 157-169 (164). On matters of patentability the underlying rationale is the same. The European Court of Justice likewise argued that an invention must be regarded as unpatentable even if the claims of the patent do not concern the use of human embryos where the implementation of the invention requires the destruction of human embryos. To argue otherwise would make the exclusion from patentability redundant by allowing a patent applicant to avoid its application by skilful drafting of the claim. ECJ, Oliver Brüstle v. Greenpeace eV, European Court Reports 2011 I-09821, Case C34/10, ECLI:EU:C:2011:669, paras 49-50.

57 On therapeutic cloning, see para. 7.

58 On this issue, see para. 8.

59 Open Door and Dublin Well Woman v. Ireland (n. 25), para. 68. Parrillo v. Italy (n. 12), para. 183. See also the joint dissenting opinion of Judges Türmen and others attached to Evans v. The United Kingdom (n. 6), para. 12. 


\section{The Limits of the Margin of Appreciation}

The essential premise from which any reasoning about the status of the human embryo should start is that an embryo, as a form of potential human life, cannot be reduced to a possession. Given the simple fact that embryos are 'human', they cannot be considered to be res or reduced to genetic material devoid of intrinsic value. ${ }^{60}$ Therefore, under no circumstances should human embryo donation be regulated as a commercial transaction. The Oviedo Convention and the EU Charter on Human Rights are both clear in prohibiting any financial gain from the human body and its parts: 'The human body and its parts shall not, as such, give rise to financial gain.' ${ }^{61}$ This is a first limit which member states cannot overstep in the exercise of their margin of appreciation: the prohibition of any commodification of embryos. At the same time, the use of 'as such' makes it clear that technical acts (such as sampling, testing, storage, and culture) on human embryos may give rise to remuneration.

An alternative to natural extinction and use in scientific research exists: socalled adoption for birth. This is the only way to provide viable embryos with a concrete possibility of biological development and life, and therefore to assure spare embryos full protection. There is otherwise no chance for them to become human beings. For this reason, to comply with Article 2 paragraph $1 \mathrm{ECHR}$, member states should contemplate this possibility in their legal systems. ${ }^{62}$

A further limit which cannot be overstepped is the requirement that whatever destination the embryos have - scientific research or adoption for birth - donors are given full information on the implications of that destination and should give free and informed consent. Certainly, a law which required women to use the embryos themselves would violate their right to determine whether or not to become a parent. A law which forcefully required the couple to allow their embryos to be 'adopted' by a third party would likewise violate their fundamental right not to be compelled into

60 At the same time, we have seen above that, according to the Court, embryos are not persons in the full and actual sense. The distinction between goods and persons, which was traditionally conceived as a summa divisio, seems to be in parte qua overcome: 'même s'ils ne sont pas tout à fait des personnes, les embryons, même cryoconservés, sont donc un peu plus que des biens'. Caire (n. 48), 739. Human embryos escape from the alternative between persons and things, which was traditionally considered a strict alternative (tertium non datur).

61 Article 21 of the Oviedo Convention; Article 21 para. 1 of the Additional Protocol concerning Transplantation of Organs and Tissues of Human Origin; in similar terms, see Article 3 para. 2 c) of the EU Charter on Human Rights.

62 See n. 21 and Maria P. Iadicicco, 'La "scelta tragica" sul destino degli embrioni non impiantati tra discrezionalità del legislatore e vaglio del giudice costituzionale’, BioLaw Journal 2/2016, 183-196 (192-193). 
parenthood.63 The same goes for a law which forcefully required spare embryos to be used for scientific research without the consent of both biological parents. As is unequivocally deducible from the Court's case law, to argue otherwise would be in sharp contrast with their right to private life.

Unlike what happens regarding the decision to interrupt or continue pregnancy, which exclusively affects the woman's body, ${ }^{64}$ in this context equal relevance must be recognised for the will of both the woman and the man. Due to them having the same biological role, both members of the parent couple should have the right to choose the final fate of the embryo in vitro, which is separate from them both, within the options laid down by the state. It is perhaps in the light of these considerations that the following obiter dictum in the Parrillo judgement must be read. The Court noted that

'the choice to donate the embryos in question to scientific research emanates from the applicant alone, since her partner is dead. The Court does not have any evidence that her partner, who had the same interest in the embryos in question as the applicant at the time of fertilisation, would have made the same choice. Moreover, there are no regulations governing this situation at [the] domestic level. ${ }^{65}$

Authoritative doctrine has considered these arguments superfluous, ${ }^{66}$ and it is admittedly true that the Court does not draw any consequence from them. However, with this statement the Court seemed to suggest that the donation of embryos to scientific research shall be subject to the coherent will of both potential donors precisely because of the respect due to both their private lives.

We saw above that the Oviedo Convention does not take a stand on the admissibility of research on in vitro embryos but at the same time requires

63 Contra the Italian Bioethics Committee: 'il Comitato ritiene che il rispetto della vita dell'embrione debba avere la priorità rispetto ad altri valori e che, pertanto, debbano essere definiti strumenti giuridici idonei a garantire agli embrioni in soprannumero una possibilità di vita e sviluppo. Ad esempio, la legge potrebbe sottrarre la disponibilità di tali embrioni alla coppia che ha accettato la loro formazione, ma non è più disposta ad accettare il loro traferimento in utero' [the Committee believes that the due respect for the life of the embryo must have priority over other values and that, therefore, appropriate legal instruments must be defined to guarantee spare embryos a chance for life and development. For example, legislation could take these embryos away from the couple who accepted their formation but are no longer willing to accept their transfer to the uterus], Italian Bioethics Committee, Identity and Statute of the Human Embryo, Advisory Opinion of 22 June 1996, 23.

64 The woman 'being the person primarily concerned in the pregnancy and its continuation or termination'. European Commission of Human Rights W. P. v. The United Kingdom, 13 May 1980, Application no. 8416/78, para. 27; R. H. v. Norway (n. 19), para. 4; Paton v. The United Kingdom (n. 19), para. 27; Boso v. Italy (n. 25), 6-7.

65 Parrillo v. Italy (n. 12), para. 196.

66 Vladimiro Zagrebelsky, “"Parrillo c. Italia.” Il destino degli embrioni congelati tra Convenzione europea dei diritti umani e Costituzione', Diritti umani e diritto internazionale 9 (2015), 609-616 (615). 
that where national law allows research on embryos in vitro adequate protection shall be assured to them. ${ }^{67}$ Admittedly, 'adequate protection' is an evocative requirement which is hard to translate into specific rules. To some extent, it might even appear contradictory because to obtain stem cells from an embryo necessarily implies irremediable impairment of its biological structure and potential for further development. Therefore, an embryo might hardly be said to be protected if it is the object of research.68

Nevertheless, a combined reading of Article 18 and other rules in the Oviedo Convention with Article 2 ECHR gives a clear indication to assess the 'adequateness' of protection. Adequate protection implies, first, that sex selection cannot be carried out, ${ }^{69}$ second, an obligation to develop guidelines and knowledge in the field of assisted fertilisation to substantially reduce the number of spare embryos, ${ }^{70}$ third, legally defining the aims of scientific research projects which might justify the 'sacrifice' of an embryo and of embryonic stem lines derived from it; fourth, ensuring that embryos are maintained under appropriate conditions for as long as is consistent with the aims of the research project and fifth, prohibiting scientific research on human embryos beyond a certain time lapse from fertilisation.

Given that the process of constitution and development of a person is a continuum, it is admittedly true that conventional borderlines are relatively arbitrary. Among the member states that allow research on the human embryo, there is, however, a clear consensus on limiting scientific research within a specific time and in any case within the first period from fertilisation. Therefore, on the one hand, the principle of 'respect for human life' is a constant throughout the period in which the embryo/foetus is developing. ${ }^{71}$ This respect provides recognition of the embryo as more than merely a part of the human body or a bundle of cells. On the other hand, the question of a 'right to life' is separate. The extent to which an embryo or foetus can be considered to possess such a right will progressively develop. Arguably, increasing legal constraints on abortion in the later stages of foetal life reflect

67 Article 18 of the Oviedo Convention.

68 For the view that any technique which implies the destruction of the embryo is incompatible with Article 18 of the Oviedo Convention, see Mathieu (n. 42), 390; Luca Marini, Il diritto internazionale e comunitario della bioetica, (Turin: Giapicelli 2006), 203; Tancredi (n. 42), 405; Adelaide Conti, Paola Delbon and Fabio Policino, 'La sperimentazione sugli embrioni umani: linee di tendenza etico-giuridiche in Europa', Rivista italiana di medicina legale 3 (2005), 549-579 (551).

69 Article 14 of the Oviedo Convention.

70 The EU Parliament 'renews its call for human artificial insemination techniques that do not produce an excess number of embryos in order to avoid generating superfluous embryos'. EU Parliament Resolution on Human Cloning, 7 September 2000, para. 7.

71 In this regard Cassiers uses the concept of 'personne progressive' - persons in progress to whom increasing respect is due in parallel with their development. Léon Cassiers, 'La dignité de l'embryon humain', RTDH 54/2003, 403-420 (416). 
a gradualist approach. For this reason, sharp borderlines need to be drawn to define the stage of development after which embryo research is prohibited.

\section{The Creation of Embryos, Parthenotes and Clones for Scientific Purposes}

The Oviedo Convention explicitly prohibits deliberately creating an embryo for research purposes ${ }^{72}$ and this practice is widely prohibited at the domestic level. This is a further limit which states cannot overstep. To admit such practice would involve using the human embryo purely as a means to an end, and would reduce it to a res to be produced and used. It is clear that this prohibition covers the creation of embryos through natural reproduction or an imitation of it, as in in vitro fertilisation. It is likewise clear that this prohibition does not cover spare embryos because they were produced for procreative, not scientific, purposes. In other words, Article 18 of the Oviedo Convention establishes the prohibition on producing embryos both in vitro and in vivo for research purposes but does not prevent research on embryos that were created for procreation purposes and then remained unused.

In contrast, it is not crystal clear whether or not this prohibition covers the creation of human parthenotes or 'cloned embryos.' To allow a lawfulness of these techniques would enable important benefits to be gained in terms of increasing scientific knowledge and developing therapies because of their potential to develop stem cells which do not even have to surmount the barrier of rejection. Parthenogenesis consists in the activation and development of an oocyte in the absence of sperm by a variety of chemical and electrical techniques, while so-called therapeutic cloning involves the transfer of the cell nucleus of a mature human (generally somatic) cell into a nonfertilised and enucleated human ovum. Both processes apparently do not involve fertilisation with gametes and for this reason might seem less controversial from an ethical point of view.

As far as parthenogenesis is concerned, in the Stem Cell Corporation case the Court of Justice of the European Union excluded parthenotes being considered embryos, starting from the assumption that an embryo to be such must be 'capable of commencing the process of development of a human being' and have an 'inherent capacity of developing into a human being'. ${ }^{73}$

72 Article 18 para. 2 of the Oviedo Convention.

73 ECJ, International Stem Cell Corporation v. Comptroller General of Patents, Designs and Trade Marks, judgment of the Court (Grand Chamber) of 18 December 2014, Case C-364/ 13, ECLI:EU:C:2014:2451. 
While meeting the first condition ('commencing'), a human parthenote does not satisfy the second ('developing into'). ${ }^{74}$ In fact, according to current scientific knowledge, mammalian parthenotes can never develop to term because, unlike a fertilised ovum, they do not contain any paternal DNA, which is required for the development of extra-embryonic tissue. Human parthenotes have been shown to only develop to the blastocyst stage, over about five days. ${ }^{75}$

Nevertheless, such arguments do not seem to conclusively exclude human parthenotes from the scope of Article 18 of the Oviedo Convention. First of all, one might say that to assume the 'inherent capacity' to develop into a human being as a decisive criterion for being an embryo is too restrictive. As long as one adopts a substantial approach to defend human life, it seems unavoidable to conclude that what matters is the potential to become a human being regardless of whether this occurs or not through an external intervention. In the Stem Cell Corporation case, the referring court stated that the applicant had amended its applications for registration to exclude the prospect of the use of any method aimed, through additional genetic manipulation, at overcoming the inability of a parthenote to develop into a human being. ${ }^{76}$ In so doing, the applicant suggested that this possibility might well exist, and was perhaps already under experimentation. In sum, focusing on the inherent capacity to develop into a human being could seem an over-weak bulwark in defence of human life.

A similar crossfire of opposite arguments can be reiterated for therapeutic cloning. One might emphasise that the aim of therapeutic cloning is to obtain stem cells to improve the quality of, or save, the life of the specific person involved, not scientific research purposes. Therefore, an element would be missing for the application of the prohibition under Article 18 of the Oviedo Convention, namely the destination 'for research purposes'. ${ }^{77}$ One might nonetheless object that to merely focus on the fact that the purpose of the

74 Stem Cell Corporation (n. 73), paras 36, 37.

75 Stem Cell Corporation (n. 73), paras 17, 33. In similar terms, Redi argues that it is inappropriate to classify the oocyte reconstructed with the nucleus of a somatic cell as a 'zygote.' Carlo Alberto Redi, 'La clonazione. Aspetti scientifici' in: Stefano Rodotà and Paolo Zatti (eds), Trattato di biodiritto (Vol. II, Milan: Giuffrè 2011), 265-279 (275). In the Stem Cell Corporation case, the EU Court of Justice overcame the broad definition of embryo previously offered in the Brüstle case as 'any human ovum after fertilisation, any non-fertilised human ovum into which the cell nucleus from a mature human cell has been transplanted and any nonfertilised human ovum whose division and further development have been stimulated by parthenogenesis.' See Bundesgerichtshof, judgment of the Court (Grand Chamber) of 18 October 2011; Oliver Brüstle v. Greenpeace eV (n. 56), para. 38.

76 Stem Cell Corporation (n. 73), para. 18.

77 In this sense, see also Carlos M. R. Casabona, 'La clonación. Aspectos éticos y yurídicos', in: Rodotà and Zatti (eds) (n. 75), 281-308 (304). 
procedure is to develop a therapy and not to produce a baby would mean ignoring the fact that the entity so produced might have that potential. ${ }^{78}$

A decisive argument to rule out the creation of human parthenotes and 'cloned embryos' from the prohibition in Article 18 of the Oviedo Convention seems to be the absence of an unequivocal practice among the state parties to the Oviedo Convention and more generally in Europe. In Italy and Switzerland, for example, therapeutic cloning is explicitly prohibited. ${ }^{79} \mathrm{In}$ contrast, other Council of Europe member states - for instance Spain, which is a party to the Oviedo Convention - recognise the legitimacy of therapeutic cloning at the domestic level. ${ }^{80}$ The issue is so delicate that the dilemma of prohibiting therapeutic cloning or not ${ }^{81}$ was a stumbling block during the

78 'It is incompatible with the Convention to produce or use living human embryos for the preparation of embryonic stem cells, or to produce cloned human embryos and then destroy them in order to produce embryonic stem cells.' Parrillo v. Italy, Concurring Opinion of Judge Pinto de Albuquerque (n. 12), para. 43. In similar terms, see also Tancredi, who argues that the prohibition on creating embryos under Article 18 of the Oviedo Convention covers therapeutic cloning. Tancredi (n. 42), 405. In this sense, see also the unequivocal, but perhaps outdated, EU Parliament Resolution on Human Cloning: 'Therapeutic cloning, which involves the creation of human embryos solely for research purposes, poses a profound ethical dilemma, irreversibly crosses a boundary in research norms and is contrary to public policy as adopted by the European Union.' EU Parliament Resolution on Human Cloning, 7 September 2000, para. 2. For an overview of the different positions at stake, see The Protection of the Human Embryo in Vitro, Report by the Working Party on the Protection of the Human Embryo and Foetus of 19 June 2003, 29.

79 For Italy, see Law no. 40/2004, Norme in materia di procreazione medicalmente assistita, Article 13, para. 3 (c); for Switzerland, see Law no. 810.31 Legge federale concernente la ricerca sulle cellule staminali embrionali, 19 December 2003, Article 3 (c).

80 See Article 33 para. 2, Ley de Investigaciòn Biomédica no. 14/2007 of 3 July 2007.

81 A further issue is of course whether Article 1 of the Protocol on the Prohibition of Cloning Human Beings, which prohibits creating 'a human being genetically identical to another human being, whether living or dead' also covers therapeutic cloning. On the one hand, the norm does not even mention therapeutic cloning and seems to only refer to the activity of reproduction of cloned human beings, which of course is not the purpose of therapeutic cloning. (In this sense, see Simone Penasa, 'La questione delle cellule staminali. Il quadro giuridico', in: Rodotà and Zatti (eds) (n. 75), Vol. V, 1101-1118 (1110). Moreover, the Protocol seems to keep the door open for such techniques given that the preamble refers to 'scientific developments in the field of mammal cloning, particularly through embryo splitting and nuclear transfer' and is mindful of 'the progress that some cloning techniques themselves may bring to scientific knowledge and its medical application'. These arguments are nonetheless rebuttable to prove that therapeutic cloning is covered by the prohibition. First of all, the absence of any explicit reference to therapeutic cloning in the provision can be interpreted not only as proof that it was expressly omitted from the reach of the prohibition. This silence can also be interpreted as an indication that it was not explicitly excluded from its scope. The EU Charter on Human Rights, for example, explicitly and solely prohibits reproductive cloning (see Article 3 para. 2 d) EU Charter on Human Rights). The Explanations Relating to the Charter coherently say that the Charter 'prohibits only reproductive cloning. It neither authorises nor prohibits other forms of cloning.' Given the omission of 'reproductive' in the Protocol, one might argue that the Protocol prohibits human cloning tout court, without any distinction between reproductive and therapeutic cloning (in this sense, see Marini (n. 68), 203). 
negotiations on the International Convention Against the Reproductive Cloning of Human Beings. ${ }^{82}$ The non-unequivocal practice, even among the state parties to the Oviedo Convention, clarifies that the core of Article 18 is the prohibition on creating embryos for research purposes through fertilisation in vitro or in vivo, without prejudice to the possibility of creating human parthenotes and 'cloned embryos' for the same purposes. This of course does not affect the right of the state parties to establish a wider measure of protection than is stipulated in the Oviedo Convention ${ }^{83}$ and thus prohibit the creation of human parthenotes and 'cloned embryos. ${ }^{84}$ The principles outlined assure the embryo a minimum standard of protection and constitute a sort of bioethics common law in Europe.

\section{Proportionality Assessment}

We saw above that the ethical dilemma concerning the embryo is unsolvable, in the sense that there are good arguments to prove that it should be treated as a human being and the same arguments can, however, also be rebutted. However, assuming for a while that the potential human life of an embryo deserves legal protection as if the embryo were a human being, one should assess whether a blanket ban on scientific research on spare embryos is a reasonable and proportionate measure to this end. In Parrillo v. Italy, the Court argued that even a blanket ban would not overstep the wide margin of appreciation enjoyed by the member states. One could, however, doubt whether this conclusion might still be valid today.

The answer cannot but be negative. As long as the legislative ban on scientific research on spare embryos remains, the only permissible fate for them, without the prospect of a future implant, is their indefinite cryopreservation, natural extinction, and subsequent destruction. The legal protection of an underlying 'right of the embryo' could not become generally effective. Indeed, notwithstanding their potential for life in abstracto, these embryos have no concrete chance of developing and becoming human beings. ${ }^{85}$

82 In the end, the negotiation for a convention was postponed and instead UNGA Resolution 59/280 was adopted. United Nations Declaration on Human Cloning, 8 March 2005, A/ $\mathrm{RES} / 59 / 280$. On this issue, see further Thibaut Lahalle, 'Clonage et dignité humaine', RTDH 54/2003, 441-481; Tancredi (n. 42), 402-403; Giuseppe Nesi, 'Il divieto di clonazione di esseri umani. Recenti dibattiti in ambito Nazioni Unite' in: Boschiero (ed.) (n. 42), 447-452.

83 See, Article 27 of the Oviedo Convention.

84 For Switzerland, see the previously mentioned Law no. 810.31 Legge federale concernente la ricerca sulle cellule staminali embrionali, 19 December 2003, Article 3 (c); (d).

85 In this sense, see Casonato (n. 56), 162-163; Lorenzo D’Avack, Il progetto filiazione nell'era tecnologica. Percorsi etici e giuridici, (Turin: Giapichelli 2014), 134-135; Marilisa D'Ami- 
It is admittedly true that the alternative between natural extinction and use in scientific research is not exclusive. Adoption for birth could be a further option. But it would not be conclusive, first because of the impressive number of embryos that have been stored so far. ${ }^{86}$ Second because a preimplantation genetic diagnosis might reveal that some embryos are not genetically healthy or are affected by organismic death because the cellular reproduction process has irreversibly stopped in them. It is commonly believed that after a time lapse of cryopreservation, embryos lose their capacity to properly develop and, once implanted, they could even jeopardise the woman's health. It seems that for them there is not even a potential life to protect. $^{87}$

Given that national laws in the Council of Europe member states generally allow the abortion of a viable foetus, it is hard to see how a blanket ban on scientific research could be justified to protect the 'potential for life' of a non-viable embryo. ${ }^{88}$ Then, since it is commonly considered lawful to derive stem cells from an aborted foetus, it is hard to understand why this cannot also be performed in advance on cryopreserved and non-viable embryos, which could be reasonably assimilated with aborted foetuses: an abortion could be taken for granted in the case of implantation. ${ }^{89}$

One might object that to admit experimentation on spare embryos could as an unacceptable effect trigger the creation of surplus embryos in vitro with the sole purpose of allocating them to scientific research, regardless of specif-

co, 'La corte costituzionale chiude la porta agli scienziati in nome della dignità dell'embrione', BioLaw Journal 2/2016, 171-181 (176).

86 Judge Sajó ironically said 'Perhaps, then, the Government [the respondent state] expects that humanity will develop the scientific ability to grow a human being from an in vitro embryo without the use of a uterus?' Dissenting Opinion of Judge Sajó in Parrillo v. Italy (n. 12), para. 15 footnote n. 16.

87 A part of the Italian National Bioethics Committee had proposed an analogy between the removal of blastomers (but the same can be said of stem cells) from embryos no longer implantable and the practice of organ donation ex mortuo. Contra, a part of the Committee supported the view that "Gli embrioni "non impiantabili", pur se caratterizzati da gravi anomalie, sono esseri umani a pieno titolo, allo stadio iniziale del loro sviluppo, e possiedono di conseguenza una assoluta dignità che ci impone di rispettarne e di proteggerne sempre la vita.' ['Non-implantable' embryos, even if characterised by serious anomalies, are human beings in their own right, in the initial stage of their development, and consequently possess an absolute dignity that requires us to respect and always protect their life]. The fate of embryos resulting from medically assisted procreation and not complying with the conditions for implantation, Advisory Opinion of the National Bioethics Committee of 26 October 2007, 6-11.

88 Dissenting Opinion of Judge Sajó in Parrillo v. Italy (n. 12), para. 13.

89 In this sense, see also Gianni Baldini, 'Embrioni soprannumerari, ricerca scientifica e divieti normativi. Riflessione a margine delle prime pronunce della giurisprudenza italiana e della Corte EDU', BioLaw Journal 2/2016, 271-288 (280). 
ic reproductive purposes. This is the well-known slippery slope argument. ${ }^{90}$ Nevertheless, such fears do not seem to be legitimately justified. This risk seems to be to a large extent mitigated if state parties establish precise conditions for the lawful creation of spare embryos and subsequent use in scientific research.

A final common objection is then grounded on the dignity which is assumed to be inherent in each and every human embryo regardless of whether or not there are any possibilities of implantation..$^{91}$ Not even the state of disease in which non-implanted embryos may be found could justify their destruction in violation of their dignity. ${ }^{92}$ One might, however, object that the very condition in which spare embryos are indefinitely stored in liquid nitrogen and without any prospect of future development is factually equivalent to a condition of death and abandonment. This very situation is detrimental to their dignity and devoid of guarantees for them. ${ }^{93}$

At the end of the day, if human embryos were to deserve absolute protection in the name of their inherent dignity, not only scientific research on the human embryo, but also post-coital contraception, selection among fertilised eggs, and a fortiori abortion would have to be coherently prohibited. As premised, the spare embryos issue itself is a side effect of the removal of the prohibition on creating more than a specific number of embryos and of the combined obligation to simultaneously implant them which were originally

90 ' $[\mathrm{L}] \mathrm{e}$ respect de tout humain est une valeur qui fonde la vie sociale et nous protège tous. Il n'existe que signifié par des règles exigeantes et rigoureuses [...] A leur apporter des exceptions, ne risquet-on pas d'affadir cette valeur de respect que les citoyens se doivent entre eux?' Cassiers (n. 71), 403-404; Habermas (n. 40), 72; Marini (n. 68), 210.

91 'The majority forget that human dignity makes it imperative to respect "the uniqueness and diversity" of each human being, as the Universal Declaration on the Human Genome and Human Rights puts it. In other words, every human being is far more than a unique combination of genetic information that is transmitted by his or her progenitors.' Concurring Opinion of Judge Pinto de Albuquerque (n. 12), para. 33.

92 Mathieu supports the view that, whatever the stage of development, research on embryos cannot be allowed because it is contrary to their inherent dignity. The author draws a parallel between the instrumentalisation of human embryos and the treatment of black people during slavery. Mathieu (n. 42), 387, 396.

93 D'Amico (n. 85), 176; Casonato (n. 56), 162. Emphasis on dignity can be found both in the writings of those who consider destruction of embryos for scientific purposes a dignified destiny and in the writings of those who consider it the most undignified end conceivable. This shows the ambivalence of the notion 'dignity' across radically opposed positions. In this sense, see also Francesco Salerno, 'International Protection and Limits to the Right to Self-Determination for the Bio-Technological Strengthening of One’s Own Person' in: Debora Provolo, Silvio Riondato and Feridun Yenisey (eds), Genetics, Robotics, Law, Punishment (Padova: Padova University Press, 2014), 437-458 (452); Francesco Francioni, 'Genetic Resources, Biotechnology and Human Rights: The International Legal Framework' in: Francesco Francioni (ed.), Biotechnologies and International Human Rights (Oxford/Portland: Hart 2007), 3-32 (20). 
contemplated in domestic laws. ${ }^{94}$ The removal of this limit was the result of a balance of the protection of the human embryo with the couple's right to have children and with the woman's right to health. ${ }^{95}$

A blanket ban on scientific research in the name of the protection of a potential for life which cannot ever materialise seems an unreasonable and disproportionate interference in the right to respect for the private life of potential donors and disregards the value system of the Convention, which recognises the interest in scientific research in its Article 10.96

\section{Final Remarks}

The spare embryo issue calls for the solution of a dilemma: whether in the name of their inherent potential for life it is appropriate, or even compulsory, to exclude any form of invasive, manipulative or destructive experimental activity on embryos and to keep them indefinitely in cryopreservation, even without any prospect of future development, or whether this unavoidable fate of abandonment and death may justify their 'sacrifice' to take further steps in scientific research against serious human diseases.

According to a personalist and sacred concept of human life, an embryo is a human being. Therefore, scientific research on the human embryo, however promising, should be excluded. Some arguments might well support this thesis. Nevertheless, starting from this premise, the fate of spare embryos could be nothing but one. So-called adoption for birth is the only way to provide viable embryos with a concrete possibility of biological development and life, and therefore to assure spare embryos full protection. There is otherwise no chance for them to become human beings. But adoption for birth would not be conclusive, first because of the impressive number of embryos that have been stored so far. Second because a preimplantation genetic diagnosis might reveal that some embryos are not genetically healthy

\footnotetext{
94 This was explicitly admitted by the Italian Constitutional Court in judgment of 22 March 2016 (n. 3), para. 8.2.

95 In this sense, but with a critical approach, see Razzano (n. 10), 231.

96 The Court in Costa and Pavan v. Italy likewise noted that Italian legislation lacked consistency in the area under analysis in that case: on the one hand it banned implantation limited to embryos unaffected by a disease of which the applicants were healthy carriers, while on the other hand it allowed the applicants to abort a foetus affected by the disease. With regard to this inconsistency in Italian legislation on preimplantation genetic diagnosis, the Court considered that interference with the applicants' right to respect for their private and family life was disproportionate and so found a violation of Article 8 ECHR. Costa and Pavan v. Italy (n. 4), paras 64-71.
} 
or are affected by organismic death because the cellular reproduction process has irreversibly stopped in them.

Given the insurmountable limits of adoption-for-birth, it is crystal clear that prohibiting scientific research on human embryos can only generally result in their indefinite cryopreservation until their natural demise. This shows that such a prohibition is unreasonable and inconsistent with the alleged aim to protect their potential life and dignity. Indefinite cryopreservation would expose embryos to unavoidable deterioration and death, and would ultimately reduce them to objects, which is in sharp contrast with life and dignity.

To use spare embryos for scientific research and for developing medical therapies seems to be the only reasonable available option. Of course, this does not mean that Member States enjoy an unlimited discretion to regulate scientific research on human embryos as they wish. First of all, being a potential human life, an embryo cannot be reduced to a possession, nor to genetic material devoid of intrinsic value. Therefore, under no circumstances should human embryo donation be regulated as a commercial transaction.

A further limit which cannot be overstepped is the requirement that whatever destination the embryos have - scientific research or adoption for birth - donors are given full information on the implications of that destination and should give free and informed consent. As is unequivocally deducible from the Court's case law, to argue otherwise would be in sharp contrast with their right to private life. Unlike what happens regarding the decision to interrupt or continue pregnancy, which exclusively affects the woman's body, in this context equal relevance must be recognised for the will of both the woman and the man. Due to them having the same biological role, both members of the parent couple should have the right to choose the final fate of the embryo in vitro, which is separate from them both, within the options laid down by the state.

Then, a combined reading of Article 18 and other rules in the Oviedo Convention with Article 2 ECHR gives a clear indication to assess the 'adequateness' of protection due to embryos. Adequate protection implies, first, that sex selection cannot be carried out, second, an obligation to develop guidelines and knowledge in the field of assisted fertilisation to substantially reduce the number of spare embryos, third, legally defining the aims of scientific research projects which might justify the 'sacrifice' of an embryo and of embryonic stem lines derived from it; fourth, ensuring that embryos are maintained under appropriate conditions for as long as is consistent with the aims of the research project and fifth prohibiting scientific research on human embryos beyond a certain time lapse from fertilisation. 
Given that the process of constitution and development of a person is a continuum, it is admittedly true that conventional borderlines are relatively arbitrary. Among the member states that allow research on the human embryo, there is, however, a clear consensus on limiting scientific research within a specific time and in any case within the first period from fertilisation. For this reason, sharp borderlines need to be drawn to define the stage of development after which embryo research is prohibited.

Finally, the Oviedo Convention explicitly prohibits deliberately creating an embryo for research purposes and this practice is widely prohibited at the domestic level. This is a further limit which states cannot overstep. Of course, this prohibition does not prevent research on embryos that were created for procreation purposes and then remained unused.

Letting embryos languish indefinitely until such (unknown and unknowable) time when they have lost viability or thawing and throwing away embryos are respectively equivalent to slow or quick deaths of embryos and ultimately cannot be accepted either by the proponents of using embryos for scientific research or by those who reject this in the name of the inherent dignity of the human embryo. Hundreds of thousands of embryos are stored and 'ask' for a better fate than being indefinitely frozen in the polar cold. 
